\title{
The invisibility of the translator in environmental translation
}

\author{
Llum Bracho Lapiedra and Penny MacDonald \\ Universitat Politècnica de València
}

\begin{abstract}
The question concerning the visibility of the translator has been widely discussed in translation studies from different ideological positions, especially during the so-called post-structuralism period. Unlike other types of translation such as audiovisual or literary translation, in the case of specialized translation the translator's name rarely appears, as demonstrated in previous research, in which, from an ambidirectional corpus in Catalan of environmental texts, in only $16 \%$ of cases was the translator's name made explicit (Bracho, 2004, p. 318). In the present article, therefore, we study a current sample with similar features to that of the original corpus, with the aim of analyzing its profile and determining the behaviour, in this sense, more than a decade after our previous conclusions.
\end{abstract}

Keywords: specialised translation, environmental translation in Catalan, translator visibility, translator's name, corpus

\section{Introduction}

In translation studies as in other linguistic or social disciplines, the visibility of the translator has been an issue widely discussed from different ideological positions especially during the so-called post-structuralism period. In spite of some opinions concerning the determination of this visibility in the translation, many authors coincide in demanding that translator names appear in translated works (Venuti, 1986, 1995; Pym, 1997; Liu, 2011, to name a few). In fact, Franco Aixelá (2004, p. 2) points out that, apart from the case of audiovisuals and literature, UNESCO has joined in this debate with a specific request which recognises that in specialised translations the name of the translator rarely appears. Clearly, it is diffuicult to hold translators responsible for their work if they are not required to put their name to it. 
The present study aims to analyse this phenomenon in the context of environmental translations, and in particular, when involving the Catalan language in the translation process. The data collected from a previous corpus along with that provided by a new updated corpus were analysed. Initially, the objective was to compare the two corpora in order to carry out a study related to how the data had evolved over time. However, due to the fact that the two corpora have different profiles, caused by the variation in the socio-temporal factors during the period of collection of the data, it was not possible to carry out a direct comparison of both. In spite of this, we have been able to draw some interesting conclusions, similar to those presented by Franco Aixelá, taking into account the profile and characteristics of each corpus.

\section{The translator's invisibility}

A translator's visibility (or invisibility) is an issue that has been broadly discussed throughout the study of translation and, specially, during the period known as post-structuralism. It all began with Venuti $(1986,1995)$ who advocated for the visibility of the translator as a recognized author and fought against the imperialism of English expressed through the foreignization of translations in order to bring this visibility to the language.

Venuti also considers how translation can create possibilities for cultural resistance, innovation, and change. He argues in his preliminary comments that 'any agenda of cultural resistance for translation must take specifically cultural forms, must choose foreign texts and translation methods that deviate from the canonical or dominant ones,' Translation should, where appropriate, reveal and accentuate difference.

(Schäffner, 1995, p. 3)

The concept of the translator's visibility has been one of the most controversial issues in the field of traductology since the publication of the article "The translator's invisibility", published by Venuti (1986) together with his book from 1995 on the history of translation with the same title as the article. In fact, in the field of traductology many academics have supported this theory because when a translation is considered 'successful' it should not appear to be a translation. In accordance, one of the techniques applied, especially concerning cultural elements, is the socalled domestication (naturalization or adaptation) of these to the culture of arrival in contraposition to concepts like foreignization. Venuti is completely against English translation, thus this domestication means the neutralization of other cultures and the hegemony of the English culture: "the more fluent the translation, the more invisible the translator, and, presumably, the more visible the writer or 
meaning of the foreign text" (Venuti, 1995, p. 2). The same way, he rejects the so-called plain English since it also brings a standardization of the language and, therefore, an adaptation of this language for the general public. Additionally, at a supra-textual level, he advocates for the role of the translator as a creative author. Most times the name of the translator does not appear in the reference section and is not considered on a legal level.

Translators are routinely alienated from the product of their work through relations of production that more closely resemble those determining labour in such other sectors of the economy as the manufacturing and service industries. Standard contracts force them to surrender all rights of ownership in the translated text at least for as long as it remains in print and sometimes for the full term of the copyright, which is usually in the publisher's name. (Venuti, 1986, p. 180)

Nevertheless, this posture was criticised by other translatologists. This is the case of Anthony Pym in his article "Venuti's visibility" (Pym, 1996) published in Target, or the case of Hatim and Mason (1997). Pym's critiques state the impossibility of defining the limits of Anglo-American culture through the use of poor argumentations as asseverations of Venuti's hypothesis. They also mention a lack of precision in defining strategies to follow in order to prevent the current situation of the translation field.

Yet the ideological bases for a non-repressive multicultural society are surely to be found in liberal humanism and its great tradition of tolerance. In his sociological projection, Venuti is accepting the fruits of this tradition: he wants to incorporate marginalised groups into a greater and even more democratic regime. In his political discourse, though, he still retains Althusser's anti-humanism and the resistence on hard, uncompromising revolutions but somewhat wanting on cultural diversity. What remains patently invisible is how Venuti's anti-humanism thought can at the same time defend the ideological bases of a multicultural society.

(Pym, 1996, p. 176)

On the other hand, Hatim and Mason (1997) consider that it is not possible to generalize the terms domestication and foreignization since these are not imperialist in an abstract sense and are, instead, dependent on the culture of their arrival as well as on the relationship with the culture of the origin.

Thus, it is not domestication or foreignization as such which is 'culturally imperialistic' or otherwise ideologically slanted; rather, it is the effect of a particular strategy employed in a particular socio-cultural situation which is likely to have ideological implications. It is in this sense that translating is, in itself, an ideological activity.

(Hatim \& Mason, 1997, p. 146) 
In sum, translation, like any other production type, is conditioned by the ideological factors in the context motivating the text. Even the theories that demand neutrality, impartiality and objectivity from the translator, are defending an ideological position, as Theo Hermans affirms:

Today, at any rate, the idea of neutral description is generally viewed with suspicion in the human sciences. There are good reasons for this. The very fact that all linguistic utterances, including descriptions, imply modal aspects is hard to reconcile with the idea of neutrality; the translation researcher does not observe or comment from nowhere in particular but from a certain institutional position; the claim to neutrality or objectivity is already an ideological statement in itself; understanding, whether in terms of Popper's searchlight theory or in more hermeneutic terms, is possible only from a given point of view, starting from preconceptions.

(Hermans, 1999, p. 36)

In studies about translation there has been (and still is) a long debate among detractors and supporters of these two ideological positions that include diverse perspectives (such as feminism, a defence of minoritary and/ or minoritized languages and cultures, etc.). Besides the authors already mentioned, other works should be included, most of which are centered on literature: Carneiro (2009), Orgiu (2011), Liu (2011) and Almeida (2012). Others advocate for the role of women in this profession: Arrojo (1994, 1997), Von Flotow (1997), Godayol (2000), Healy (2004). There is an anti-colonial ideological position defended by Bhabha (1994), Robinson (1997) and Spivak (1999), and another one focusing on ethics supported by Monzó (2003), Franco Aixelá (2004), Rao (2004) and Pym (2010). This research brings the development of concepts like the domestication/foreignization, ethics, responsibility, servility, loyalty and even happiness generated in translating (Liu, 2011, 2013a, 2013b).

This author, in her doctoral thesis, gave statistical evidence after carrying out a survey among fellow translators of Chinese origin, of the close relationship there is between translator visibility, social relations, cultural knowldege and learning, and satisfaction perceived in the translator's work:

Our first hypothesis, that the more visible the translators, the more capital they receive, has been confirmed. [...] the correlations between the translator's visibility and the social as well as the cultural capital that the translators say they receive are strong and significant. [...] the more visible the translators the more social and cultural capital they receive, are confirmed in a statistically significant way. These test results suggest that people may not receive more money or enjoy higher prestige/status when they are visible to their clients and end-users. However, when they are visible, they do have a stronger social network, and they feel that they are learning more. $[\ldots]$ We have also confirmed that the more visible the translators, 
the less the gap between capital sought and capital received. In addition, it has also been statistically proven that the more visible the translators, the more and greater positive emotions they experience when they deal with translation. (Liu, 2011, p. 169) [...] the translator's visibility has a greater impact on job-related happiness than does the translator's work experience. (Liu, 2011, pp. 169-170) [...] In general terms, in this sample, it was found that visibility is rewarding in terms of social exchanges and learning experience, but not in terms of pay and prestige.

(Liu, 2011, pp. 181-182)

Moreover, in line with the results of this researcher, visibility and the explicit naming of the author are two aspects that are unquestionably related, since specifying the translator's name, is directly concerned with the satisfaction obtained from the finished work and the professional experience gained. However, according to the results in Liu's research, this is irrelevant when considering the translator's own preferences with regard to visibility:

All these correlation tests suggest that, in our sample, the appearance of a translator's name on translations is related to the translator's visibility, the capital received, job-related happiness and work experience, but it is not related to the translator's visibility preference. Although the last correlation cannot be explained, it can be speculated that a translator's name on translations is related to the person's discursive presence in translations, while visibility preference is about the subject's personal preferences for working in a way that is visible to clients and end-users. (Liu, 2011, p. 180) [...] What was found to be significantly related to the translator's visibility, the capital received, and job-related happiness is the appearance of a translator's name on translations.

(Liu, 2011, pp. 181-182)

Nevertheless, most research referencing this topic includes three central issues that are initially different, although non-exclusive (Hönig, 1997): (a) The translator's (more or less) ideological mark in the job, (b) the translator's presence in the translation's paratexts and (c) the indication of the translator's name in the final translated product. In the words of Koskinen (2000), we could say that, the first case could include researchers who are focused on the study of "the ways in which the translator makes his or her presence visible on the textual level, in the translation itself". The second case includes studies that refer to "the translator's statements about their work outside or in the margins of the actual text" and lastly, we can find studies that focus on "the requirement that the name of the translator be mentioned in publisher's publicity material" (p. 99). It is importat to add that not all authors agree with this classification. For example, the explicitation of the name ("presence") is not considered visibility, but "different dimensions of presence" (Mailhac, 1997, p. 35). In any case, the last issue commented is the one specifically addressed in this work. 
In 1997, Anthony Pym proposed a series of ethical principles in relation with the translator's work based on responsibility in translation, clientele and the profession. These are outlined in five points (our translation from the original French):

First principle: The translator is responsible for his or her product from the moment they agree to do it. The key question is not How to translate? - further question -, but: Should it be translated? Then, in that moment, from that text, with or without enough support?

Second principle: The translator is responsable as long as he or she is professional. Let's understand what that means. The translator is not directly responsable for the content to translate, for the translation rules, for the stupidity or cleverness of the client, nor for the specific working conditions. Therefore, the translator fulfills the responsibility as such due to the decision originally made to translate (or not) a text.

Third principle: The translating processes should not be reduced to the opposition of two cultures. We reject all binary oppositions of languages, societies and classes, under a critique to sell itself. We also mention that the translator is not a brave supporter, with rigurous intercultural ethical beliefs. It is false to try to undermine his and her actions under unique cultural criteria.

Fourth principle: The amount of resources spent on the translation should not surpass the benefit of the value in the corresponding intercultural relation. This is an aspect that is usually ignored by those who consider a translator as a machine that can do everything. The social effort invested in translation is as important as the quality of the resulting text.

Fifth principle: The translator, a simple advisor, is responsable for making his or her work contribute to establishing an intercultural collaboration that is stable and long term. Since we have tried to clear the history of the Spartans, this aim implies the "limitation of suffering" and "respect for one another", which are general criteria for intercultural relations that are both, fair and referring to the living. [Italics correspond to the author's voice].

All in all, in reference to the objectives of our research work, the absence of the explicitation of the translator's name in its products is a usual practice that we now analyse in the case of environmental translation in Catalan, but is also extrapolated to other scientific and technical fields. As Franco Aixelá explains, "even now, when Unesco demands that the name of the translator should always be included, the name of technical translators is hardly ever to be found in any corner of their published work, especially in scientific journals" (Franco Aixelá, 2004, p. 2).

Although we agree with Pym's reflection (perhaps the editors should be included, not in all cases) on the ethical responsibility of translators, there are two questions we could ask ourselves. On one side we wonder how to demand more 
accountability from translators when their names do not appear on the text. On the other, we think about the possible influence of this situation in the ethical responsibility towards the translation itself, the clients and the profession itself. Lastly, we wonder about the reasons why the translator's name is not included in environmental and, perhaps by extension, scientific and technical texts.

\section{Objectives, methodology and corpus description}

We would like to begin by mentioning that in earlier research, we studied this phenomenon, also in environmental translation, through a corpus that contained a wide range of textual genres (guides, leaflets, textbooks, reports, legal documents) as well as degrees of specialization (including informative texts). We also considered ambidirectional translation of texts in Catalan and other European languages produced within different environments (administration, business, associations, etc.). General conclusions from this study found that only $16 \%$ of the texts explicitly showed the translator's name (Bracho, 2004, p. 318).

In the present study we propose a comparative study between the earlier corpus and current research that includes similar features to the orginal corpus. The goal is to analyse the evolution of translator visibility in environmental translation and to determine which behaviours have developed more than a decade after our earlier conclusions.

However, the difference found in the socio-temporal factors affecting the two corpora have conditioned the results of the research to such an extent that although both corpus had been randomly compiled using the same search model and by extracting information from the same sources, the final results are not in reality comparable, with the exception of some coincidences in general characteristics. In this sense it is important to point out that the criteria for document extraction and selection applied in both cases has been that Catalan language be part of the translation, not only as a language of origin but also as one of arrival, within the field of environmental sciences, independently from other participating languages, fields of use, textual genres and degrees of specialization that were encountered.

Results obtained show the general differences in the current corpus, outlined in Table 1. In first place, it is necessary to point out that we were not intending to use the same amount of documents as presented before, with 94 documents models $^{1}$ (393 original texts and their translations). In the later corpus we aim to include

1. We talk about "document model" in reference to group of texts that hold similar elements that characterize them within these corpora (environment, participating languages, directivity, 
a representative sample that has generated a result of 58 document models ${ }^{2}$ (156 texts and their translations). When it comes to time limitations, while the texts from the earlier research date between 1983 and 2003 (two decades), the current study includes texts from 2004 until today (a period of 12 years).

Table 1. General differences between the 2004 and the 2016 corpora

\begin{tabular}{ll}
\hline Earlier work (2004) & Current work (2016) \\
\hline 1983-2003 & $2004-2016$ \\
8 languages: +italian -bulgarian & 8 languages: +bulgarian -italian \\
94 document models & 58 document models \\
393 originals +translations & 156 originals +translations \\
Fields of use & Fields of use: -press \\
Textual genres: +variation & Textual genres: -variation \\
\hline
\end{tabular}

In addition, the list of the languages participating in both corpora matches, minus the case of Italian, not included in the current corpus, as can be seen in Table 2. Although Bulgarian is included in the corpus, its presence is only testimonial. In general, the majority of the texts that constitute this study are in Spanish, English and, obviously, Catalan, with similar percentages in each corpus, and with a smaller participation from other languages.

Table 2. Participating languages and percentage of texts in the 2004 and 2016 corpora

\begin{tabular}{lcc}
\hline & Earlier work (2004) & Current work (2016) \\
\hline Catalan & 100 & 100 \\
Spanish & 80 & 91,38 \\
English & 55 & 60,34 \\
French & 16 & 5,17 \\
German & 9,6 & 6,9 \\
Italian & 7,4 & 0 \\
Portuguese & 7,4 & 1,72 \\
Euskera & 1,1 & 1,72 \\
Bulgarian & 0 & 1,72 \\
\hline
\end{tabular}

genre, etc.) For exemple, two issues of the same magazine with the same characteristics in relation to the descriptive languages studied would belong to the same document model.

2. Due to the large amount of bibliographical references making up both corpora, these are not cited in this article. Nevertheless, the 2004 corpus can be consulted in Bracho (2004, 2010). At the end of this article the organisms who produced the documents are mentioned. 
In relation to the environments of usage defined by the research, whereas in 2004 we found texts that appear in four usage environments shown in Table 3, in the current corpus we have not found texts translated from or into Catalan in the press. We have some ideas of which diverse factors could have influenced in this circumstance. For example, an environmental summit took place in Barcelona in 2004 that brought up official publications of news in three languages. Another reason is the disappearance of journalistic publications that translated from other European languages. This was the case of the Catalan version of Le Monde diplomatique.

Table 3. Fields of use and percentage of texts in the 2004 and 2016 corpora

\begin{tabular}{lll}
\hline & Earlier work (2004) & Current Work (2016) \\
\hline Administrations & 46,81 & 41,38 \\
Associations & 29,78 & 39,65 \\
Businesses & 15,96 & 18,97 \\
Press & 7,45 & 0 \\
\hline
\end{tabular}

It is important to mention that nowadays we can find many online pages in Catalan on environmental topics. Many of these pages can be accessed through other languages. However, in many cases we find the information to be incomplete depending on the version or the information included hypertextually. When one is sent to a document or node (Díaz, 2002, p. 216) through a link, this appears in its original language, not in the translated version, which would be coherent from the point of view of the reader. ${ }^{3}$

Therefore, the fact that a particular web page can be consulted in diferent languages does not mean that the information is actually available in all those languages initially detailed on the web page. In reality, in the majority of cases, only the main web page is translated, and it is often the case that this can be seen to be incomplete or indicating that it is still under construction. In addition, we have also found cases where the web page has different versions depending on the language used in the search engine such as in the case of the publishing company Santillana or Le Monde Diplomatique.

In general we have noticed an absence of international documents translated into Catalan, whereas nowadays many are only found in Spanish or English. Last decade, these accounted for a considerable part of the corpus. This is the specific case of Institutional Declarations (D) of European and international forms. In the case of 2004, these amounted to a notorious percentage in the corpus (see Table 4). On the contrary, during the research for the current corpus, we found

3. Other projects where we analyze hypertextuality and translation are in Bracho (2002, 2003). 
no declaration translated into Catalan because most links that mentioned them directed us to the document in its original language. In any case, we believe that the main reason for the decrease in the variation of textual genres in the current corpus is due to the smaller quantity of documents. In consequence, with regards to textual genres, as happened with the fields of use, both corpora are different.

Table 4. Textual genres and percentage of texts in the 2004 and 2016 corpora

\begin{tabular}{lcc}
\hline & Earlier work (2004) & Current work (2016) \\
\hline Declarations & 22,3 & 38 \\
Reports & 12 & \\
Press articles & 11 & 12 \\
Guides & 9,6 & 7 \\
Magazines & 8,5 & 8,5 \\
Bulletins & 6,4 & 7 \\
Leaflets & 6,4 & \\
Legal documents & 6,4 & 19 \\
Author books & 5,3 & 8,5 \\
Catalogs & 4,2 & \\
Educ. Documentaries & 3 & \\
Text books & 2 & \\
Electronic announcements & 2 & \\
Glossaries & 1 & \\
\hline
\end{tabular}

In Table 5 we offer differences between the profiles of the levels of specialization of the texts contained in each corpus. We are aware that this classification (high, medium and low degree) is not rigid and normally it is based on a more or less uniform degradation. ${ }^{4}$ In both cases the majority of texts are the ones with a medium level, despite the specific profile of each corpus, according to which dissemination texts are larger in quantity in the 2004 work, whithout noticing a great significance in this phenomenon.

4. Greg Myers also agrees with this opinion: "Such divisions between science and non-science, professional and non-professional, divisions that we take for granted, were formed in historical struggles, and are re-formed in everyday practices: the way a quoted speaker is introduced, a metaphor used instead a technical term, a table summarized and simplified." (Myers, 2003, p. 274). 
Table 5. Specialization degrees and percentages in the 2004 and 2016 corpora

\begin{tabular}{lll}
\hline & Earlier work (2004) & Current work (2016) \\
\hline Low & 30 & 12 \\
Medium & 59 & 79 \\
High & 11 & 8 \\
\hline
\end{tabular}

In contrast, when it comes to the directivity of the translation (to Catalan or from Catalan), we find significant differences in the profiles of each compilation, despite the fact that in many cases there is no explicit information provided which mentions if these are originals or translations. In addition to the difficulty that this can bring from the traductological point of view, in some cases this characteristic can be quite relevant. In certain cases it is convenient to know which is the original, as in the case of legal documents. This question was also studied in our earlier work (Bracho, 2004, p. 92), where $72 \%$ of the cases did not mention this characteristic. However, thanks to a thorough analysis of the texts, the original version was found in many cases, which reduced this circumstance to $11 \%$.

In the current corpus, even though the real percentage is smaller (31\%), we have been able to reduce this to $19 \%$ through an accurate revision of the texts. In order to determine the language directivity in both cases, we have used several clues. These consider the vehicular language of the institution or organism that produces or translates the document, further published versions, the preponderance given to a language that aims to stand out as the original of the publication, the author's origin, the location where the topic of the document is settled, the date of publication of the different versions, calques specially orthotypographical and paralinguistic (graphics, photographs of a specific language...), etc.

However, we would add that, in this process prudence has prevailed, since the directivity of the language in the process of translating through deduction has many limitations. For instance, despite its origin, an author can write in other languages, which could be different from the ones he or she normally uses. With reference to the calques, specially lexical or terminological and syntactic, these can be generated through contact between languages, which is a very common practice in the Catalan speaking environment. Additionally, the preferred choice of a language in a document does not mean that this is the language of origin, which occurs in some documents in the Catalan speaking geography.

The reasons why an original language or its translation are hidden could be related to the following: irrelevance (in the case of an informational leaflet), issues related to sociolinguistics (for example, a language's prestige in favour of another), ideological and economic reasons (there is no interest in saying explicitly which is the translation, such as in the case of documents belonging to environmental 
companies that are not publishing houses) and, lastly, the reason could be of a practical nature (where the original belongs to the organism or producer, like in the case of Diari Oficial de la Generalitat de Catalunya, DOGC o del Boletin Oficial del Estado, BOE).

With relation to the translations of the international or European administrations, it is possible that this omission has something to do with a will to treat official languages equally. For example, this happens in the case of the Catalan administration, the associations and publishing houses in the Catalan speaking environment and could be related to an aim to bring prestige to the autochthonous language. Another reason could be simply in order to hide the fact that the production is not being done in the autochthonous language (specially, when it comes to the use of a minoritized language, which is the case of Catalan). For instance, in a magazine cited in the 2004 corpus in the field of associations, the translator's names do not appear on the back cover, but there is a note indicating that the magazine is published in two versions, one in Catalan and one in Spanish: Aquesta revista també es publica en castellà, Esta revista también se publica en catalán. However, we could deduce that the original is in Catalan, specially because the title of the magazine is in Catalan: Opcions and because the second issue of the version in Spanish ${ }^{5}$ apologises for serious orthographical errors caused by time constraints in the translation and correction process for the Spanish edition: Debido a las prisas en el proceso de traducción y corrección de la edición en castellano de Opcions, quedaron algunas faltas de ortografía graves. Pedimos disculpas. Other ways to detect the original language have to do with automatic translation, without a future revision. This is the case of location names in their original version (Colombia in Spanish) ${ }^{6}$ and abbreviations, syntactic calques, etc. An example is a calque in Spanish that corresponds to the Catalan term Mecanismes de Desenvolupament Net (CDM), with the English acronym (Clean Development Mechanisms). It has been translated into Mecanismos de Desarrollo Net (CDM), possibly through the use of an automatic translator or because the Catalan term net has been confused by the English term net (network). ${ }^{7}$

5. Centre de Recerca i Informació en Consum. Opcions, núm. 2. http://cric.pangea.org/opcionscas.htm [consulta: gener 2004]. At present, the magazine is called Opciones in the Spanish version.

6. Centre d'Estudis de Dret Ambiental de Tarragona. Information Bulletin, n. 66, april 2015. http://www.cedat.cat/butlleti/html/2015/es_abril/ [seen: april 2016]

7. Fundació Terra. Perspectiva ambiental. Perspectiva escolar supplement. 25. Cuina solar. June 2002. http://www.ecoterra.org/html/cat/perspectiva/perspe.html [seen: may 2003]. 
Table 6. Catalan's directivity in the 2004 and 2016 corpora

\begin{tabular}{lcc}
\hline & Earlier work (2004) & Current work (2016) \\
\hline Direct & 69 & 27,5 \\
Reverse & 20 & 53,5 \\
$?$ & $(72) 11$ & $(31) 19$ \\
\hline
\end{tabular}

\section{Results and discussion}

The results from the analysis of both corpora aim to bring objective data on the explicitation of the translator's name in the process of translation of the studied texts. In this sense, the first data we obtained (see Figure 1) represents the percentage of model documents in which the name of the translator appears in each corpus. In both cases the number of examples is not high.

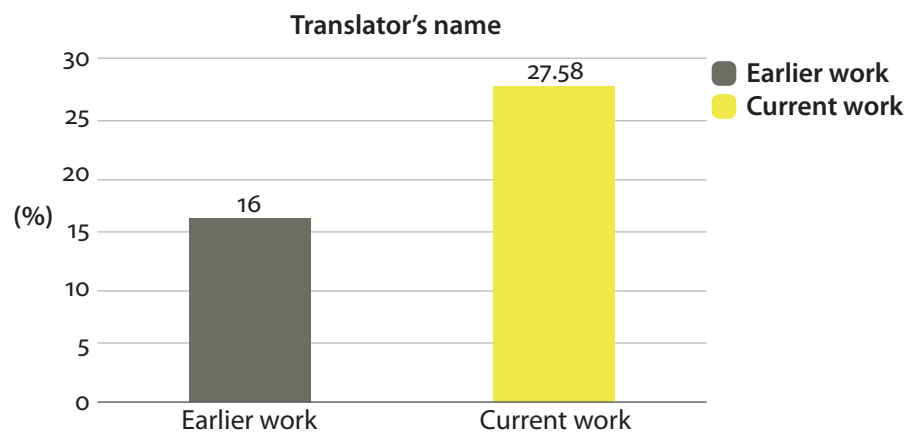

Figure 1. Explicitation of the translator's name in the 2004 and 2016 corpora

Among the percentage of explicitation in each corpus, we notice that the earlier study includes a large number of individual translators, while the current corpus includes a percentage that is now equal to translation service companies (Figure 2). 


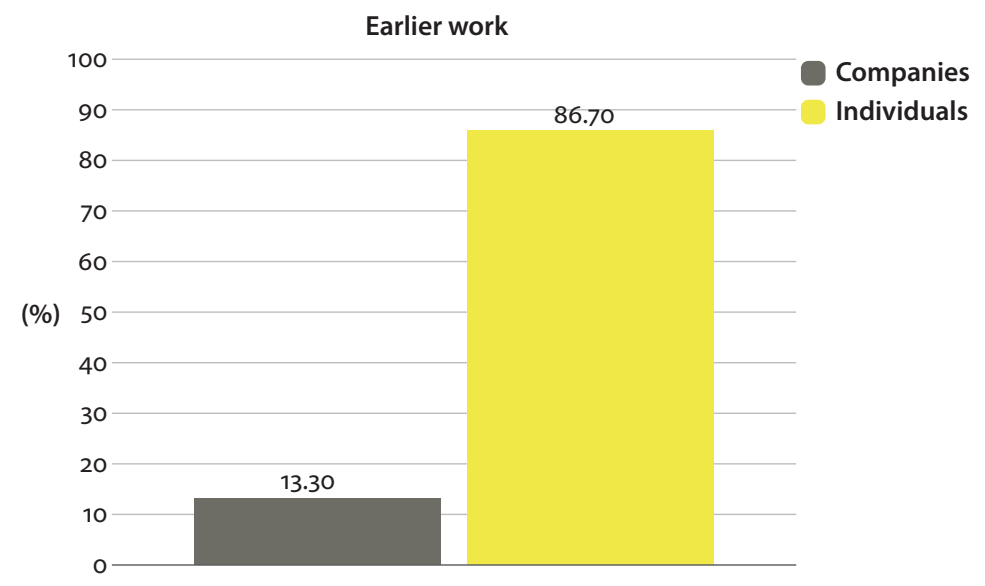

a.

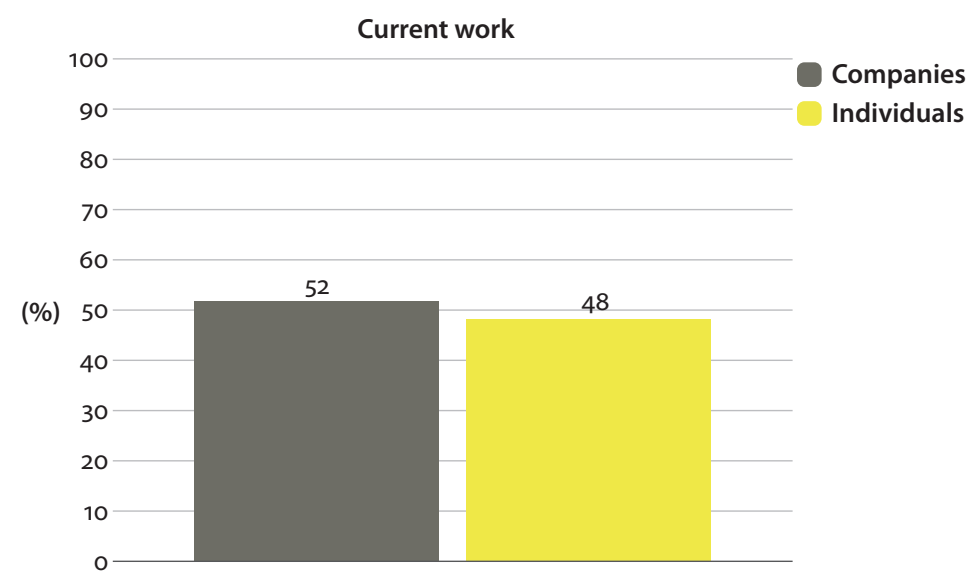

b.

Figure 2. Classification between individuals and companies regarding explicitation of the translator's name

On the other hand, Dury (2002) distinguishes between "traducteurs spécialisés non-spécialistes" (non-specialised specialised translators) and "traductors spécialisés spécialistes" (specialists specialised translators), considering the first to be "linguistes de formation, et pour des raison professionalles, en viennent à la traduction scientifique et technique" (linguists by training and, for professional reasons, turning to scientific and technical translation), while the others are related to "les écologues, les scientifiques de formation, qui pour des besoins de communication internationale se sont mis à la traduction spécialisée" (the ecologists, those trained scientists who are dependent on international communication, are in the field of specialised translation) (Dury, 2002, p. 205). In our case, the percentage of these profiles in each corpus is about a quarter in the case of professional experts, 
which allows us to think about a possible repercussion in the product translation's final quality (Figure 3).

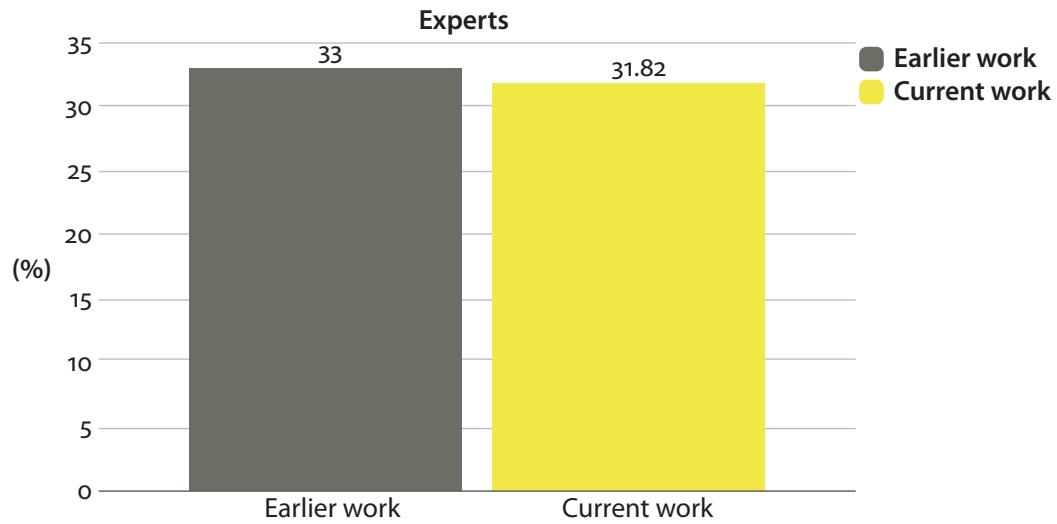

Figure 3. Profile of the translators included in the 2004 and 2016 corpora

Following this, we conduct an analysis of data relative to the explicitation of the name of the translator in each of the corpora, taking their profiles into consideration. In this way, the percentages are balanced in accordance with their average in the composition of each corpora. This way, in the case of the fields of use, we notice how, in accordance with each profile, the field where the name of the translator appears the least is administration (ADM). This occurs in both corpora (Figure 4). Whereas in the earlier work most translator name appearances correspond to the business (BUS) and press (PRE) fields, the current study shows that the largest percentage by far belongs to associations (ASS). In this sense, it is important to point out the effort that these fields have made in favour of transparency in data through, for instance, the explicitation of the translator's name.
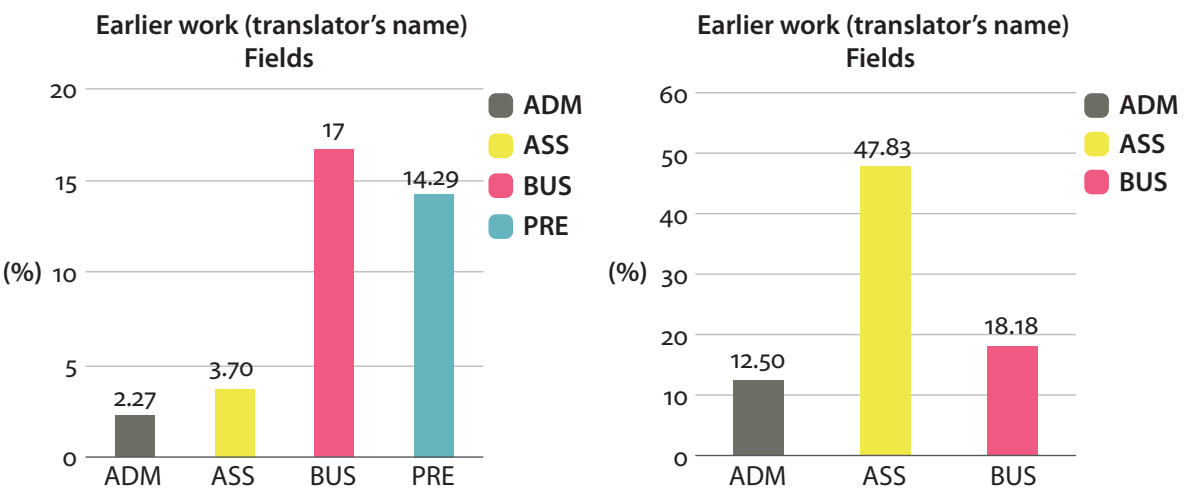

Figure 4. Explicitation of the translator in the fields of use in both corpora 
With regards to the textual genres (Figure 5), in the 2004 corpus the explicitation of the translator proportionally appears in all the genres, with a large percentage in the case of author books (B), guides (G) and textbooks (TB). This highlights the importance of a possible influence of paper print, editorial prestige and the specific characteristics of each genre (length, price) in the explicitation phenomena.

In this sense, we have noticed that an online edition always seems more provisional, given that digital elements are "elementos mucho más fluidos que los documentos tradicionales" (elements that are more fluid than traditional documents) (Cordón, 2000, p. 84), with "gran facilidad de modificación o actualización" (great capacity to be modified and updated) (Codina, 1996, p. 80). In any case, the appearance of the translator's name in magazines $(M Z)$ and reports $(R)$ is lower. In the case of Declarations (D), informational Leaflets (L) and journal Articles (A) is even smaller.
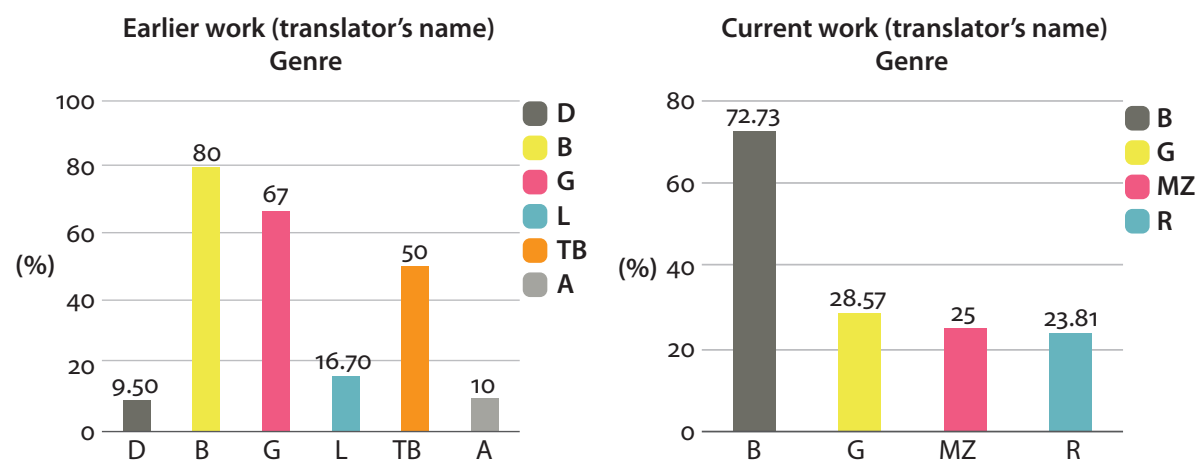

Figure 5. Explicitization of the translator in textual genres in both corpora

Furthermore, when observing the level of specialization (Figure 6), we notice that the publishing prestige does not have much to do with the academic prestige. For instance, in both corpora the absence of texts with a high degree of specialization is noticeable. Even though the percentage of texts with medium (ME) and low degrees of specialization (LO) - or non-specialized (Cabré, 1999, p. 24) ${ }^{8}$ - is completely the opposite.

8. Cabré argues that "un mismo tema puede dar lugar a textos especializados y no especializados en función del carácter referencial que transmita, de forma que, ante intenciones funcionales que alteren la referencialidad propia de cada especialidad (ironizar sobre un tema, banalizarlo hasta convertirlo en broma o chiste, metaforizar una temática para aludir a una situación distinta, etc.), los textos de temática inicialmente especializada devienen textos no especializados" (Cabré, 1999, p. 24). 
Earlier work (translator's name) Degree

(\%)

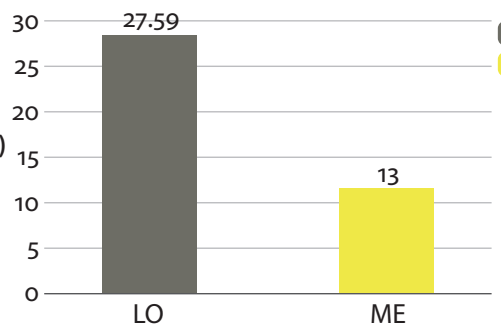

Current work (translator's name)

Degree

LO

ME

(\%)

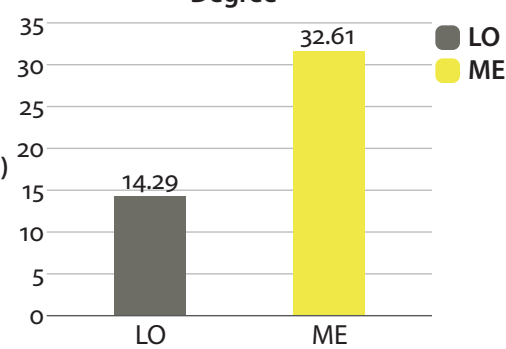

Figure 6. Explicitation of the translator according to the specialization degree in both corpora

In the case of Catalan's directivity (Figure 7), superiority in the explicitation of the translator in texts translated into Catalan (DI) can be seen. The causes for this tendency can be found in the language prestige (or lack of it), and, in the case of the language in question, it is not considered to be of prestige in the scientific world (Pueyo, 1998, p. 129).
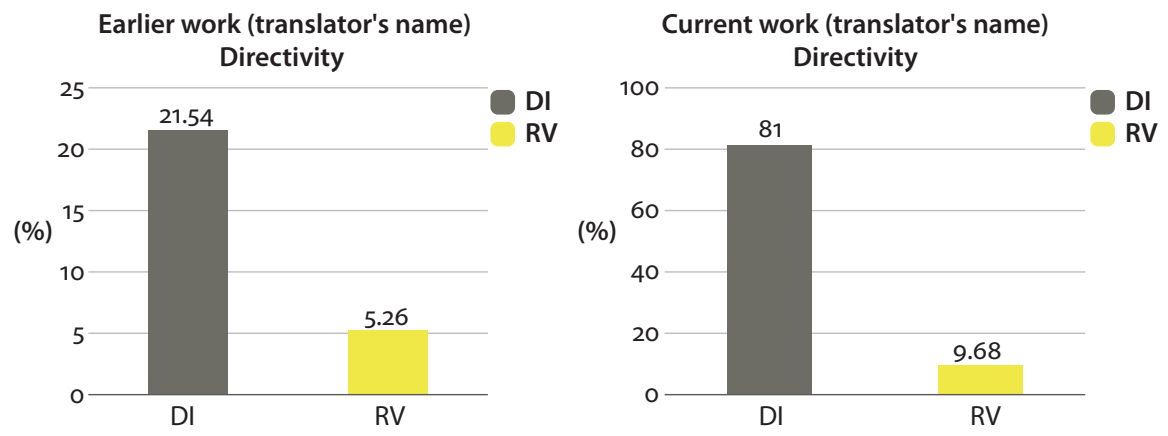

Figure 7. Explicitation of the translator according to Catalan's directivity in both corpora

\section{Conclusions}

In this study we aim to analyse the treatment applied to the translator's visibility with regards to the explicitation of the name, through a corpus of environmental texts in Catalan created earlier (in 2004) in comparison with a current corpus (from 2016). Social and temporal factors have influenced the compilation of both corpora and produced results with different profiles. This makes their comparison problematic in absolute terms, since it has not been possible to subject the evolution of translator behaviours to our analysis, although it can be said that the study 
has allowed us to reach conclusions with regards visibility in a relative way to the profile of each corpus.

If we focus on the description of both corpora, despite the profile differences between these, we notice similarities when it comes to participating languages, where a clear hegemony of texts in Spanish and English is established in Catalan ambidirectional translation of environmental texts. This is similar when considering the proportion of fields of use due to the impossibility of finding translations from the press in the current corpus, owing to the already mentioned contextual factors (disappearance of the Catalan version of a given newspaper, absence of environmental meetings and summits within the Catalan language environment, etc.).

Significant differences in the profile of both corpora are found in the smaller variation of textual genres in the current corpus. This is possibly due to the lower amount of samples and to the Catalan language's directivity in the current corpus, which is inverted with regards to percentages. But, if we consider the actual explicitation of which is the original and which is the translated text, this is larger in the current corpus, which can be valued as positive, although the number of cases of non-explictation is still high.

On the other hand, in relation to the explicitation of the translator's name, we confirm that there is a low percentage appearing in both corpora. In addition, in the current corpus the percentage is also low with regard to the use of a personal name in detriment of a company name, which is considered to be the possible cause of a reduction in the responsibility of the translator towards the potential reader. Moreover, a quarter of the total amount of explicitations of both corpora corresponds to translators specialized in environmental knowledge, which, together with the low explicitation, could influence the final quality of the product. It is also probable that the translator's low professional specialization is a piece of information that should be considered as one of the possible reasons for the lack of explicitation of their names.

When it comes to use, in both corpora we can see that administrations are the ones who hide name explicitation the most, while in the current corpora, by far, associations are the ones that explicitate it the most, probably in pursuit of ethical transparency. On the other hand, in both cases, author books (together with textbooks and guides) represent the largest percentage of textual genres, possibly as a response to editorial prestige.

In the case of the specialization level, even though the percentages of low and middle degrees in both corpora are inverted, the total absence of the translator's name in documents with high degree of specialization is significant. This coincides with what Franco Aixelá (2004) asserts, indicated at the beginning of this article. Lastly, in the cases in which Catalan is the language of origin, there is not 
a proper explicitation of the translator's name, which is possibly related to the scientific or technical prestige of the translations.

To conclude, on one hand, it is difficult to demand the translator's responsibility on the final work if they are not cited as such. On the other hand, it seems that results from the analysis of both corpora coincide in the fact that, in the case of environmental translation in Catalan, the absence of this responsibility is directly related to the prestige of the language of origin (Tuson, 1998; Solà, 2003) ${ }^{9}$ - specially if there is an official patronage - and if a text is constituted as a translation and not an original.

\section{Acknowledgements}

This article has received financial support from research projects FFI2015-68867-P, funded by the Spanish Ministry of Economy and Competitiveness.

\section{Sources in environmental corpora ${ }^{10}$}

ACC Assessors Ambientals de Catalunya, S. L. Website Languages: Catalan and Spanish: http:// www.ambientals.com/

Agència de Residus de Catalunya de la Generalitat de Catalunya. Website Languages: Catalan, Spanish and English: http://residus.gencat.cat/ca/index.html

Agencia Estatal Boletín Oficial del Estado - Ministerio de la Presidencia del Gobierno de España. Website Languages: Spanish, Portuguese (Galician), Catalan, Basque, English and French: https://www.boe.es/

Aiguasol Enginyeria. Website Languages: Catalan, Spanish and English: http://aiguasol.coop/

Ajuntament d'Elx. Website Languages: Catalan and Spanish: http://www.elche.es/?set_ language $=\mathrm{va}$

Ajuntament de Barcelona. Website Languages: Catalan, Spanish and English: http://ajuntament. barcelona.cat/ca/

Amics de la Terra Eivissa. Website Languages: Catalan and Spanish: http://cat.amics-terra.org/ Arema, Agua, Residuos y Medio Ambiente. Website Languages: Catalan, Spanish, English, French and Bulgarian: http://www.arema.com/es/

9. According to this author, "[...] a pesar de todos los avances de la lengua catalana en nuestra sociedad, esta lengua sigue siendo una lengua de segunda, poco importante o poco seria; no saberla o no saberla bien es la cosa más natural del mundo, a nadie produce rubor ni preocupación alguna." (Solà, 2003, p. 52).

10. Some of these organisms have ceased to function or have changed their names slightly over time. As mentioned previously, although the web pages can be consulted in these languages, the actual documents therein do not always appear in the same language as that offered on the main page. 
Associació de municipis catalans per a la recollida porta a porta. Website Languages: Catalan, Spanish and English: http://www.portaaporta.cat/ca/index.php

Bundesministerium für Bildung und Frauen (Austrian Federal Ministry of Education and Women's Affairs. Before, Austrian Federal Ministry of Education, Science and Culture). Website Languages: German and English: https://www.bmbf.gv.at/enfr/index.html

Centre d'Estudis d'Informació Ambiental, CEIA. Institut Català de Tecnologia (non-existent now)

Centre de la Propietat Forestal, Generalitat de Catalunya. Website Languages: Catalan, Spanish and English: http://cpf.gencat.cat/ca/

Centre de Recerca Ecològica i Aplicacions Forestals, CREAF, Generalitat de Catalunya. Website Languages: Catalan, Spanish and English: http://www.creaf.cat/ca

Centre de Recerca i Informació en Consum, CRIC. Website Languages: Catalan and Spanish: http://opcions.org/cric

Centre d'Educació Ambiental de la Generalitat Valenciana. Website Languages: Catalan and Spanish: http://www.agroambient.gva.es/ca/web/ceacv

Centre d'Estudis de Dret Ambiental de Tarragona, CEDAT. Website Languages: Catalan, Spanish and English: http://www.cedat.cat/

Centre Tecnològic Forestal de Catalunya, CTFC. Website Languages: Catalan, Spanish, English and French: http://www.ctfc.cat/

Clean Clothes Campaign. Website Language: English: http://www.cleanclothes.org/

Comissions Obreres del País Valencià CCOO-PV. Website Languages: Catalan (some documents in Spanish, some in Catalan): http://www.pv.ccoo.es/

Conselleria d'Habitatge, Obres Públiques i Vertebració del Territori de la Generalitat Valenciana (before Conselleria de Medi Ambient). Website Languages: Catalan and Spanish: http:// www.habitatge.gva.es/va/conselleria

Consumer (Eroski Consumer). Website Languages: Catalan, Spanish, Basque and Portuguese (Galician): http://www.consumer.es/

Council of Europe). Website Languages: English, German, French, Italian and Russian: http:// www.coe.int/en/

Council of European Municipalities and Regions, CEMR. Website Languages: English and French: http://www.ccre.org/

DEPANA. Website Language: Catalan: http://www.depana.org/public/

Departament de Territori i Sostenibilitat de la Generalitat de Catalunya (before Departament de Medi Ambient). Website Languages: http://territori.gencat.cat/ca/inici/

Diari Oficial de la Generalitat de Catalunya. Website Languages: Catalan and Spanish: http:// dogc.gencat.cat/ca/

Diputació de Barcelona. Website Languages: Catalan, Spanish and English: http://www.diba.cat/ Earth Policy Institute. Website Language: English: http://www.earth-policy.org/

Earthscan Publications Ltd (Routledge, Taylor \& Francis Group). Website Language: English: https://www.routledge.com/sustainability

Ecoinstitut Barcelona. Website Languages: Catalan, Spanish and English: http://www.ecoinstitut. coop/

Edicions Bromera. Website Language: Catalan: http://www.bromera.com/

Esquerra Unida del País Valencià, EUPV. http://eupv.org/ Website Language: Catalan

Europa Press. Website Language: Spanish: http://www.europapress.es/

European Commission. Website Languages: English, Spanish, French, Bulgarian, Czech, Danish, German, Estonian, Greek, Gaelic, Croatian, Italian, Latvian, Lithuanian, Hungarian, 
Maltese, Dutch, Polish, Portuguese, Romanian, Slovak, Slovenian, Finnish and Swedish: http://ec.europa.eu/index_en.htm

European Sustainable Cities and Towns Campaign. Website Language: English: http://www.sustainablecities.eu/

Fundació Bancaixa - Bankia. Website Languages: Catalan and Spanish: http://www.fundacionbancaja.es/val/

Fundació Centre d'Estudis Ambientals del Mediterrani, CEAM, de la Generalitat Valenciana. Website Languages: Catalan, Spanish and English: http://www.ceam.es/GVAceam/home. htm

Fundació Fòrum Ambiental. Website Languages: Catalan and Spanish: http://www.forumambiental.org/

Fundació natura - Acciónatura. Website Languages: Catalan, Spanish and English: http://www. accionatura.org/

Fundació Terra. Website Languages: Catalan, Spanish and English: http://www.fundaciontierra. es/ca

Fundació territori i paisatge de la Caixa de Catalunya (now Fundación Global Nature). Website Language: Spanish: http://www.fundacionglobalnature.org/patrocinadores/fundacion_ territori_i_paisatge.htm

Gas natural - Fenosa. Website Languages: Catalan, Spanish and Portuguese (Galician): http:// www.gasnaturalfenosa.es/html/esp_hogar/home_hogar/index.html?id=ca

Grup62. Website Language: Catalan: http://www.grup62.cat/

ICLEI Europe. Local Governments for Sustainability. Website Languages: English: http://www. iclei-europe.org/

Institut Català de l'Energia, ICAEN, de la Generalitat de Catalunya. Website Languages: Catalan and Spanish: http://icaen.gencat.cat/ca/index.html

Institut Internacional de Governabilitat de Catalunya (non-existent now)

Inter Press Service. Website Languages: English, Spanish, Arabic, Italian, Japanese, Dutch, Portuguese, Finnish, Suec, Swahili and Turkish: http://www.ipsnews.net/

La Casa Verda - Acció ecologista Agró. Website Language: Catalan: http://www.accioecologistaagro.org/

Le Monde diplomatic. Website Language: http://www.monde-diplomatique.fr/ (non-existent now in Catalan; it also exists in English and Spanish versions)

L'Entesa (non-existent now)

LGAI. Website Language: English: http://www.v-c-s.org/vvb/lgai-technological-center-sa-applus (now Applus, non-existent in catalan)

Los Verdes de Benidorm (before Els Verds de Benidorm). Website Language: Spanish: https:// www.facebook.com/Los-Verdes-de-Benidorm-1479464875651734/

McGrau-Hill Education. Website Language: Spanish: http://www.mheducation.es/index.php

Oficina Catalana del Canvi Climàtic (Before Oficina del Canvi Climatic) de la Generalitat de Catalunya. Website Languages: Catalan, Spanish and English: http://canviclimatic.gencat. $\mathrm{cat} / \mathrm{ca} /$

Partit Socialista de les Illes Balears, PSIB. Website Language: Catalan: http://www.psib-psoe.org/ Partit Socialista del País Valencià, PSPV. Website Language: Catalan: http://www.pspvpsoe.net/

Publicacions de la Universitat de València. Website Languages: Catalan and Spanish: http://puv. uv.es/

Retorna. Website Languages: Catalan, Spanish, Basque and Portuguese (Galician) http://www. retorna.org/ca/ 
SETEM Catalunya. Website Languages: Catalan, Spanish and English: http://www.setem.org/ site/cat/catalunya/

Simon \& Schuster. Website Language: English: http://www.simonandschuster.com/

Societat Catalana d'Educació Ambiental, SCEA. Website Languages: Catalan, English, French and Spanish: http://www.scea.cat/WEB2015/

TFM Energia Solar Fotovoltaica S.A. Website Languages: Catalan and Spanish: http://www.tfm. es/index_cat.php

The EarthWorks Group (non-existent now)

The Economist. Website Language: English: http://www.economist.com/

The Landmark Project. Website Languages: Catalan, English, German, Spanish and Portuguese: http://www.landmark-project.eu/

Uniland Cementera - Ciment Català. Website Languages: Catalan, Spanish and English: http:// www.ciment-catala.org/epub/easnet.dll/execreq/page?eas:dat_im=0001A8\&eas:template_ im $=000419$

Union of Concerned Scientists. Science for a healthy planet and safer world. Website Language: English: http://www.ucsusa.org/

United Nations Educational, Scientific and Cultural Organization. Website Languages: http:// en.unesco.org/

United Nations Sustainable Development Knowledge Platform (before United Nations World Commission on Environment). Website Languages: English, French, Spanish, Russian, Arabic and Chinese: https://sustainabledevelopment.un.org/csd/csd.htm

University of California Press. Website Language: English: http://www.ucpress.edu/

Voramar - Santillana. Website Languages: Catalan (There exists a Spanish version): http://www. santillana.es/ca/

Weltwirtschaft, Ökologie \& Entwiclung (World Economy, Ecology \& Development), WEED. Website Languages: English and German: http://www.weed-online.org/

WorldWatch Institute. Website Language: English: http://www.worldwatch.org/

\section{References}

Almeida, G. (2012). La (in)visibilidad de la traductora: La traducción del inglés al español del cuento "Spanish winter" de Jennifer Egan. Master's dissertation. Florida: Florida Atlantic University.

Arrojo, R. (1994). Fidelity and the gendered translation. TTR, 7(2), 147-163. doi: 10.7202/037184ar

Arrojo, R. (1997). The "death" of the author and the limits of the translator's visibility. In M. Snell-Hornby, Z. Jettmarová, \& K. Kaindl (Eds.), Translation as intercultural communication (pp. 21-32). Amsterdam: John Benjamins. doi: 10.1075/btl.20.04arr

Bhabha, H. K. (1994). The location of culture. London: Routledge.

Bracho, L. (2002). Mecenatge i traducció en la difusió del discurs ambiental. In J. Chabás, R. Gaser, \& J. Rey (Eds.), Translating science: Proceedings of the 2nd International Conference on Specialized Translation. (pp. 201-210). Barcelona: Universitat Pompeu Fabra.

Bracho, L. (2003). La traducció de revistes mediambientals en Internet. In J. Piqué-Angordans, M. J. Esteve, \& M. L. Gea-Valor (Eds.), Internet in language for specific purposes and foreign language teaching (pp. 115-122). Castelló de la Plana: Universitat Jaume I. 
Bracho, L. (2004). La traducció en el discurs mediambiental en llengua catalana: Anàlisi i caracterització d'un corpus ambidireccional. Doctoral thesis. Castelló de la Plana: Universitat Jaume I.

Bracho, L. (2010). Environmental translation in Catalan: Culture, ideology and the environment. Saarbrücken, Germany: Lambert Academic Publishing.

Cabré, M. T. (1999). Fuentes de información terminológica para el traductor. In M. Pinto \& J. A. Cordón (Eds.), Técnicas documentales aplicadas a la traducción (pp. 19-39). Madrid: Síntesis.

Carneiro, M. F. (2009). O paratexto o a visibilidade do traductor. Rio de Janeiro: Universidade Católica do Rio de Janeiro. Master's dissertation.

Codina, L. (1996). El llibre digital: Una exploració sobre la informació electrònica i el futur de l'edició. Barcelona: Generalitat de Catalunya.

Cordón, J. A. (2000). Fabulaciones y confabulaciones: Las paradojas del escrito en la era Internet. In C. Gonzalo \& V. García Yebra (Eds.), Documentación, terminología y traducción (pp. 83-96). Madrid: Síntesis.

Díaz, J. (2002). La escritura digital: Hipertexto y construcción del discurso informático en el periodismo electrónico. Zarautz: Servicio Editorial de la Universidad del País Vasco.

Dury, P. (2002). La terminologie diachronique, une aide à la traduction spécialisée: L'exemple de l'ecologie. In J. Chabás, R. Gaser, \& J. Rey (Eds.), Translating science: Proceedings of the 2 nd International Conference on Specialized Translation (pp. 201-210). Barcelona: Universitat Pompeu Fabra.

Franco Aixelá, J. (2004). The study of technical and scientific translation: An examination of its historical development. The Journal of Specialised Translation, 1. Retrieved from http:// www.jostrans.org/issue01/art_aixela.pdf.

Godayol, P. (2000). Espais de frontera: Gènere i traducció. Vic: Eumo.

Hatim, B., \& Mason, I. (1997). The translator as communicator. London/New York: Routledge.

Healy, M. (2004). The cachet of the "invisible" translator: Englishwomen translating science (16501850). Canada: University of Otawa. Doctoral thesis.

Hermans, T. (1999). Descriptive and system-oriented approaches explained. Manchester: St. Jerome Publishing.

Hönig, H. G. (1997). Positions, power and practice: Functionalist approaches and translation quality assessment. Current Issues in Language and Society, 4(1), 6-34. doi: $10.1080 / 13520529709615477$

Koskinen, K. (2000). Beyond ambivalence: Postmodernity and the ethics of translation. Doctoral thesis. Tampere: University of Tampere.

Liu, F. M. C. (2011). A quantitative and qualitive inquiry into translators' visibility and job-related happiness: The case of greater China. Doctoral thesis. Tarragona: Universitat Rovira i Virgili.

Liu, F. M. C. (2013a). A quantitative enquiry into the translator's job-related happiness: Does visibility correlate with happiness? Across Languages and Cultures, 14(1), 123-147. doi: 10.1556/Acr.14.2013.1.6

Liu, F. M. C. (2013b). Revisiting the translator's visibility: Does visibility bring rewards? Meta: Translator's Journal, 58(1), 25-57. doi: 10.7202/1023808ar

Mailhac, J. P. (1997). The debate: Visibility of the translator and readers' receptions. Current Issues in Language and Society, 4(1), 35-55. doi: 10.1080/13520529709615478

Monzó, E. (2003). Un marc per a la visibilitat del traductor: Reflexions des de la traducció jurídica i jurada. Traducción \& Comunicación, 4, 55-84. 
Myers, G. (2003). Discourse studies of scientific popularization: Questioning the boundaries. Discourse Studies, 5(2), 265-279. doi: 10.1177/1461445603005002006

Orgiu, S. (2011). La invisibilidad del traductor: Los traductores holandeses de Tres tristes tigres de Cabrera Infante, ¿son visibles o invisibles? Master's dissertation. Utrecht: University of Utrecht.

Pueyo, M. (1998). Bilingüisme o diglòssia?: Antaviana! In M. A. Pradilla (Ed.), Ecosistema comunicatiu: Llengua i variació (pp. 111-132). Benicarló: Alambor.

Pym, A. (1996). Venuti’s visibility. Target, 8(1), 165-177. doi: 10.1075/target.8.1.12pym

Pym, A. (1997). Pour une ethique du traducteur. Arras Cedex: Artois Presses Université.

Pym, A. (2010). Exploring translation theories. London/New York: Routledge.

Rao, S. (2004). Quelques considérations éthiques sur l'invisibilité du traducteur ou les vertus du silence en traduction. TTR, 17(2), 13-25. doi: 10.7202/013268ar

Robinson, D. (1997). Translation and empire. Manchester: St. Jerome Publishing.

Schäffner, C. (1995). Editorial. In C. Schäffner \& H. Kelly-Holmes (Eds.), Cultural functions of translation (pp. 1-8). Clevedon: Multilingual Matters.

Solà, J. (2003). Ensenyar la llengua. Barcelona: Empúries.

Spivak, G. (1999). A critique of postcolonial reason: Towards a history of the vanishing present. Harvard: Harvard University Press.

Tuson, J. (1998). Prejudicis lingüístics. In M. A. Pradilla (Ed.), Ecosistema comunicatiu: Llengua i variació (pp. 91-109). Benicarló: Alambor.

Venuti, L. (1986). The translator's invisibility. Criticism: A Quarterly for Literature and the Arts, $28(2), 179-212$.

Venuti, L. (1995). The translator's invisibility: A history of translation. London: Routledge. doi: 10.4324/9780203360064

Von Flotow, L. (1997). Translation and gender: Translating in the "Era of Feminism". Manchester: St. Jerome.

\section{Resumen}

La visibilidad del traductor ha sido una cuestión ampliamente debatida en los estudios de traducción a partir de posiciones ideológicas distintas, sobre todo durante el denominado postestructuralismo. A diferencia de otras tipologías como la traducción audiovisual o la literaria, en la especializada son pocos los casos donde aparece su nombre, como demostramos en un trabajo de investigación anterior, en el que, a partir de un corpus ambidireccional en catalán de textos medioambientales, sólo en un 16\% de los casos se explicitaba el nombre del traductor (Bracho, 2004, p. 318). En este trabajo, pues, estudiamos una muestra actual, con rasgos similares a la de aquel corpus, para analizar su perfil y determinar cuál es el comportamiento, en este sentido, más de una década después de nuestras conclusiones anteriores.

Palabras clave: traducción especializada, traducción medioambiental en catalán, visibilidad del/de la traductor/a, nombre del/ de la traductor/a, corpus 


\section{Authors' addresses}

Llum Bracho Lapiedra

Universitat Politènica de València

ETS d'Arquitectura

Camí de Vera, s/n

46022 València

Spain

llumbra@idm.upv.es
Penny MacDonald

Universitat Politènica de València

ETS d'Enginyeria Agronòmica i del Medi

Rural

Camí de Vera, s/n

46022, València

Spain

penny@idm.upv.es

\section{Biographical notes}

Llum Bracho Lapiedra is Doctor in Translation and Interpretation from the Universitat Jaume I in Castellón, Spain, and Associate Professor in the Department of Applied Linguistics at the Universitat Politècnica de València where she teaches Catalan for Specific Purposes. She has several publications in the field of translation including the book Environmental translation in Catalan: Culture, ideology and the environment.

Penny MacDonald has been teaching English (for Specific Purposes and Applied Linguistics) in both undergraduate and Master's degrees at the Universitat Politècnica de València since 1998. Her research focuses mainly on the study of interlanguage errors, (critical) discourse analysis, and intercultural communication at the workplace. 